\title{
Determination of Optical Parameters of Polymer Blend/Nanoceramics for Electronics Applications
}

\author{
Ahmed Hashim ${ }^{1}$, Alaa J. Kadham ${ }^{2}$, Aseel Hadi ${ }^{3}$, \\ and Majeed Ali Habeeb ${ }^{1}$ \\ ${ }^{1}$ University of Babylon, \\ College of Education for Pure Science, \\ Department of Physics, \\ Babylon, Iraq \\ ${ }^{2}$ Al-Qasim Green University, \\ College of Agriculture, \\ Department of Soil and Water, \\ Al-Qasim, Iraq \\ ${ }^{3}$ University of Babylon, \\ College of Materials, \\ Department of Ceramic and Building Materials, \\ Babylon, Iraq
}

Preparations of PVA/PEG/zirconium oxide films for biomedical application as antibacterial are investigated for electronics applications. Structural and optical characterizations of $\mathrm{PVA} / \mathrm{PEG} / \mathrm{ZrO}_{2}$ nanocomposites are examined. The results indicate that the absorbance and optical parameters of polymer blend are raised, while transmittance and energy-band gap are reduced as $\mathrm{ZrO}_{2}$ content increases. The results of structural and optical properties show that the $\mathrm{PVA} / \mathrm{PEG} / \mathrm{ZrO}_{2}$ nanocomposites may be used for various electronics fields.

Для застосування в електроніці досліджуються препарати оксидних плівок полівініловий спирт/поліетиленгліколь/оксид Цирконію для біомедичних вживань як антибактеріяльних. Розглянуто структурні й оптичні характеристики нанокомпозитів ПВС/ПЕГ $/ \mathrm{ZrO}_{2}$. Результати показують, що абсорбція й оптичні параметри полімерної суміші $€$ підвищеними, в той час як коефіцієнт пропускання та ширина забороненої енергетичної зони зменшуються в міру збільшення вмісту $\mathrm{ZrO}_{2}$. Peзультати структурних і оптичних властивостей показують, що нанокомпозити ПВС/ПЕГ $/ \mathrm{ZrO}_{2}$ можуть використовуватися для різних галузей електроніки.

Key words: zirconium oxide, nanocomposites, polymer blend, optoelectronics. 
Ключові слова: оксид Цирконію, нанокомпозити,, полімерна суміш, оптоелектроніка.

(Received 8 May, 2020)

\section{INTRODUCTION}

The nanocomposites materials are promising in the fields of sensors, radiation shielding, antibacterial, thermal energy storage and release, piezoelectric, solar cells, diodes and other fields with low cost and lightweight. The important type of nanocomposites is polymer nanocomposites. The polymer nanocomposites have unique properties, which combine between polymer properties (low cost, dielectric material, good optical properties, low thermal conductivity, and poor mechanical properties in comparison with other materials) and additive properties, that determine the properties of the resulting substance and depends on the concentration of the additive. The nanocomposites are characterized as antibacterial materials. Due to the urgent need to find materials having good antibacterial properties, it is important to determine the resistance of bacterial to the antibiotics by novel antibiotics. The applications of nanotechnology in medicine may be used for fight against many types of diseases [1]. The materials of nanoparticles have promised applications in the different fields of biomedical sciences, which are attributed to their special properties [2].

The synthesis of new polymer nanocomposites has been studied by the modern applications on inorganic nanoparticles as fillers in the several applications [3]. Organic and inorganic nanocomposites have been studied as unique type of hybrid nanomaterials attributed to their structural, electrical, optical, and thermal properties [4]. The optical characterization of nanocomposites is influenced by different factors including filler size, distribution of sizes, dispersion degree, and concentration of filler [5]. Zirconium oxide nanoparticles have a special consideration due to the unique properties for biomedical application as antibacterial material [6]. The improvements in D.C. electrical, dielectric, optical, and thermal properties of composites and nanocomposites are increasing to great potential for highly functional materials having good electrical, dielectric, optical, and thermal characterizations with low weight and low cost [723]. This paper deals with preparation and properties of $\mathrm{PVA} / \mathrm{PEG} / \mathrm{ZrO}_{2}$ nanocomposites for biomedical applications.

\section{MATERIALS AND METHODS}

Nanocomposites were prepared from polyvinyl alcohol/polyethylene 
glycol, and zirconium oxide by means of using casting method. The PVA/PEG/Z $\mathrm{ZO}_{2}$ nanocomposite was prepared with ratios of $\mathrm{ZrO}_{2}$ nanoparticles and blend: $1 \mathrm{gm}$ of PVA/PEG with ratio $78 \mathrm{wt} . \% / 22$ wt. $\%$ was dissolved in $20 \mathrm{ml}$ of distilled water. The $\mathrm{ZrO}_{2}$ was added with ratios 2, 4 and 6 wt.\%. Optical properties were measured by the spectrophotometer Shimadzu, UV at $1800 \AA$.

The absorption coefficient $\alpha$ was calculated using the equation [24-26]

$$
\alpha=2.303 A / t,
$$

where $A$ is absorbance, $t$ is thickness of sample. The energy-band gap was determined [27, 28] with

$$
\alpha h v=Y\left(h v-E_{g}\right)^{d}
$$

$Y$ is constant, $h v$ is energy of photon, $E_{g}$ is energy gap, $d=2$ and 3 for indirect allowed and forbidden transitions.

The extinction coefficient $(k)$ of nanocomposites is determined by using $[29,30]$

$$
K=\alpha \lambda /(4 \pi)
$$

The refractive index $(n)$ was calculated by using [31]

$$
n=\left(1+x^{1 / 2}\right) /\left(1-x^{1 / 2}\right) .
$$

The real $\left(\varepsilon_{1}\right)$ and imaginary $\left(\varepsilon_{2}\right)$ parts of complex dielectric constant are given by using [32]

$$
\begin{gathered}
\varepsilon_{1}=n^{2}-k^{2}, \\
\varepsilon_{2}=2 n k .
\end{gathered}
$$

The conductivity is determined by using [33]:

$$
\sigma=\frac{\alpha n c}{4 \pi} .
$$

\section{RESULTS AND DISCUSSION}

Figure 1 indicates to the absorbance variation with wavelength. The absorbance reduces with increase in wavelength. Figure also shows that the absorbance of PVA/PEG blend rises with raise in $\mathrm{ZrO}_{2}$ ratios that is related to raise the charge carries [34, 35], as shown in 


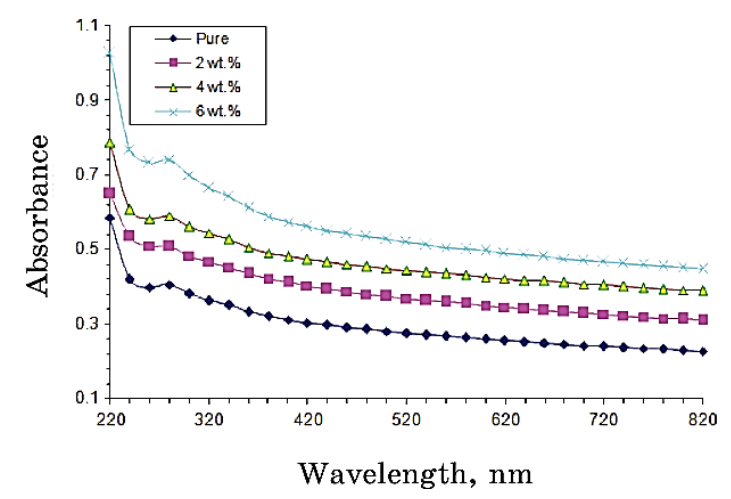

Fig. 1. Absorbance with photon wavelength.
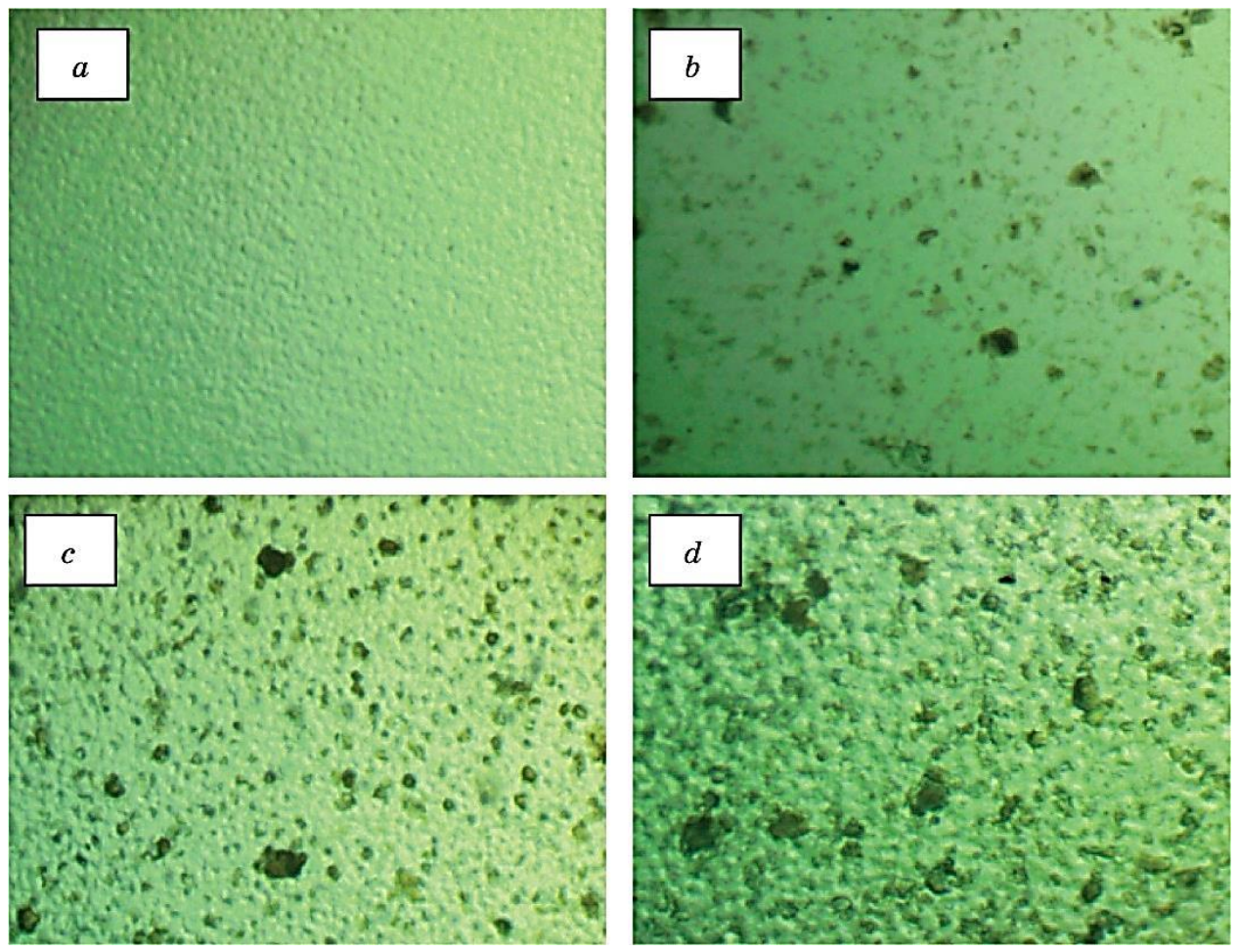

Fig. 2. Microscope images ( $\times 10)$ : (a) for pure blend, (b) for 2 wt.\% $\mathrm{ZrO}_{2}$, (c) for 4 wt. $\% \mathrm{ZrO}_{2},(d)$ for 6 wt. $\% \mathrm{ZrO}_{2}$.

Fig. 2. These are consistent with the results of Refs. [36-40]. The absorption coefficient of nanocomposites is shown in Fig. 3. It increases with an increase in $\mathrm{ZrO}_{2}$ nanoparticles. The energy gap 

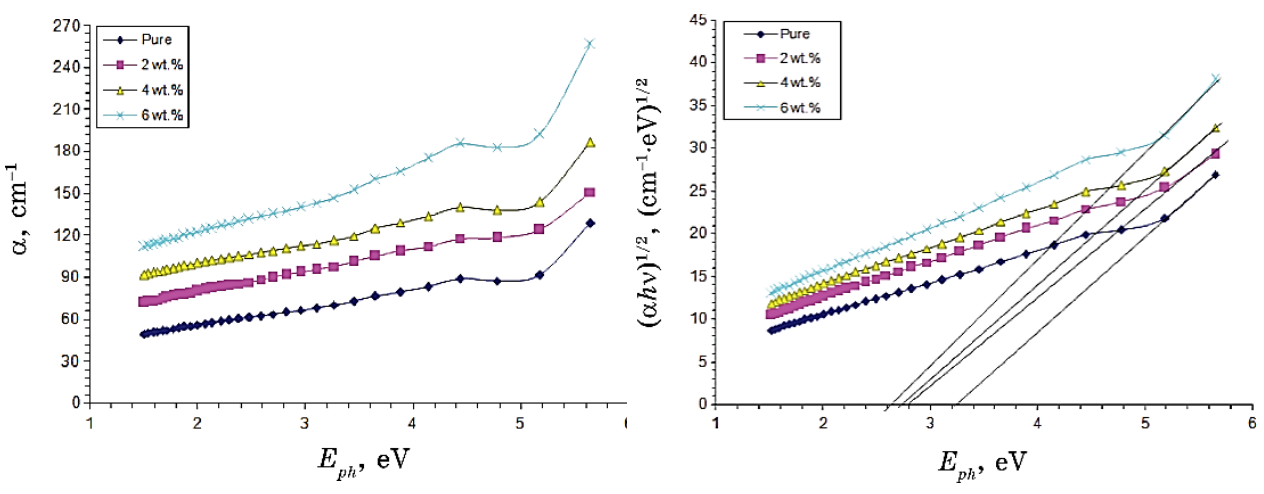

Fig. 3. Absorption coefficient for $\mathrm{PVA} / \mathrm{PEG} / \mathrm{ZrO}_{2}$ nanocomposites.

Fig. 4. Energy gap for allowed transition.
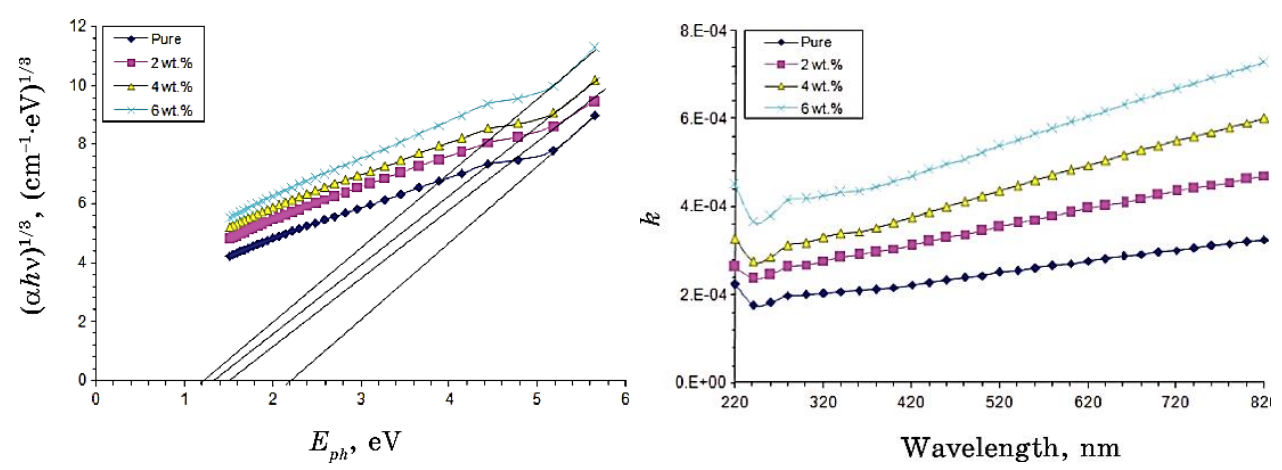

Fig. 5. Energy gap for forbidden transition.

Fig. 6. Extinction coefficient for PVA/PEG $/ \mathrm{ZrO}_{2}$ nanocomposites.

may be calculated by the values of absorption coefficient; they show that the PVA/PEG/ZrO $\mathrm{Zr}_{2}$ nanocomposites have indirect band gap for allowed indirect (Fig. 4) and for forbidden indirect (Fig. 5) transitions. The energy-band gaps of polymers decrease with increase in $\mathrm{ZrO}_{2}$ concentrations; this behaviour may be attributed to raise the localized level [41-46].

Figure 6 represents the extinction coefficient for PVA/PEG $/ \mathrm{ZrO}_{2}$ nanocomposites. There is increased extinction coefficient with increasing of the zirconium oxide concentrations that is due to increase of the absorbance [47, 48].

Figure 7 shows refractive index of $\mathrm{PVA} / \mathrm{PEG} / \mathrm{ZrO}_{2}$ nanocomposites. Refractive index of blend rises with raise in $\mathrm{ZrO}_{2}$ ratio because of raising the light scattering [49-51].

The real and imaginary parts of complex dielectric constant with wavelength are represented in Figs. 8 and 9. These parts increase 


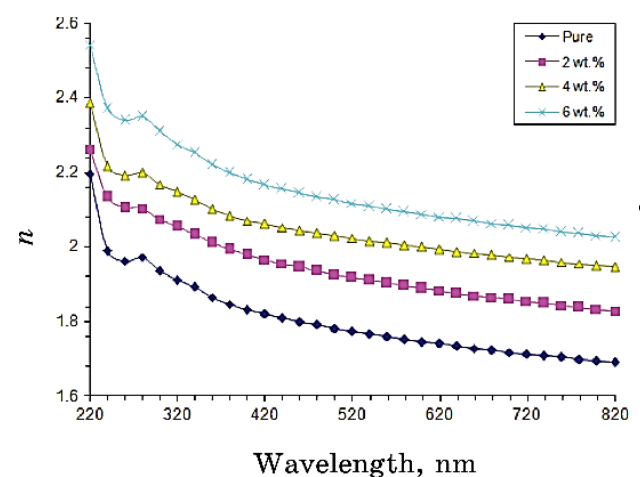

Fig. 7. Refractive index of PVA/PEG $/ \mathrm{ZrO}_{2}$ nanocomposites.

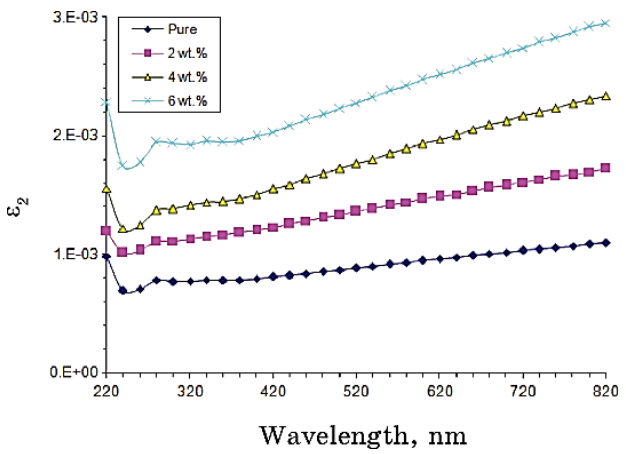

Fig. 9. Relationship between the imaginary part and photon wavelength.

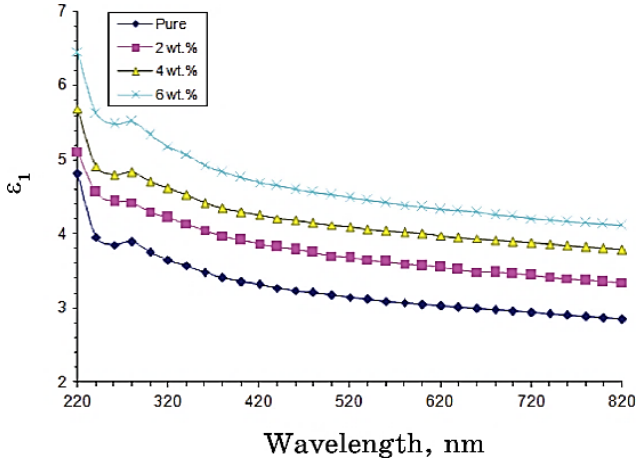

Fig. 8. Relationship between the real part and photon wavelength.

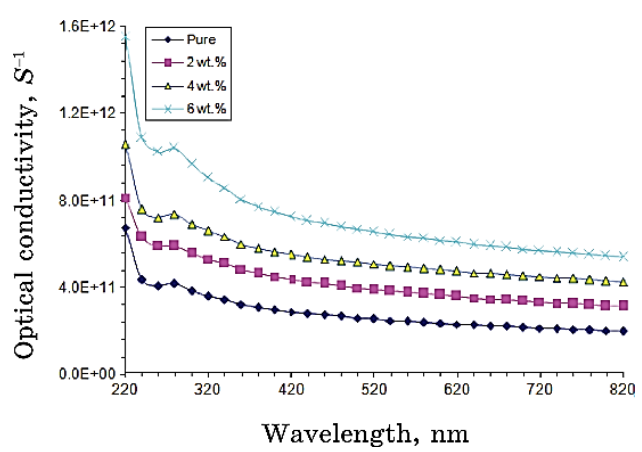

Fig. 10. Conductivity with wavelength of photon.

with the increase in $\mathrm{ZrO}_{2}$ ratios that is due to the increase in refractive index and extinction coefficient $[52,53]$.

Figure 10 indicates to the conductivity variation with energy of photon. The conductivity of polymer blend increases as $\mathrm{ZrO}_{2}$ concentration increases that is attributed to increase of refractive index and absorption coefficient [54].

\section{CONCLUSION}

Absorbance of PVA/PEG blend rises as $\mathrm{ZrO}_{2}$ content increase.

The energy gap of PVA/PEG blend reduces with raise in $\mathrm{ZrO}_{2}$ ratio.

The optical parameters are changed with raise in $\mathrm{ZrO}_{2}$ nanoparticles ratio. 
The structural and optical properties indicated that the $\mathrm{PVA} / \mathrm{PEG} / \mathrm{ZrO}_{2}$ nanocomposites might be used for different electrical and electronic applications.

\section{REFERENCES}

1. Shweta Ranghar, Parul Sirohi, Pritam Verma, and Vishnu Agarwal, Brazilian Archives of Biology and Technology, 57, No. 2: 209 (2014).

2. Sant Lal Jangra, K. Stalin, Neeraj Dilbaghi, Sandeep Kumar, Jai Tawale, Surinder P. Singh, and Renu Pasricha, Journal of Nanoscience and Nanotechnology, 12: 7105 (2012).

3. Flávio James Tommasini, Leonardo da Cunha Ferreira, Lucas Galhardo Pimenta Tienne, Vínícius de Oliveira Aguiar, Marcelo Henrique Prado da Silva, Luiz Felipe da Mota Rocha, and Maria de Fátima Vieira Marques, Materials Research, 21, No. 6: e20180086 (2018); https://doi.org/10.1590/19805373-MR-2018-0086

4. Debashish Nayak and Ram Bilash Choudhary, Optical Materials, 91: 470 (2019).

5. Haider Mohammed Shanshool, Muhammad Yahaya, Wan Mahmood Mat Yunus, and Ibtisam Yahya Abdullah, J. Mater. Sci: Mater. Electron, 27, No. 9: 9804 (2016); https://doi.org/10.1007/s10854-016-5046-8

6. Mohammed M. Gad, Ahmad M. Al-Thobity, Suliman Y. Shahin, Badar T. Alsaqer, and Aiman A. Ali, International Journal of Nanomedicine, 12: 5409 (2017).

7. Majeed Ali Habbeb, Ahmed Hashim, and Abdul-Raheem K. AbidAli, Europe an Journal of Scientific Research, 61, No. 3: 367 (2011).

8. Hayder Abduljalil, Ahmed Hashim, and Alaa Jewad, European Journal of Scientific Research, 63, No. 2: 231 (2011).

9. Z. Al-Ramadhan, Ahmed Hashim, and Alaa J. Kadham Algidsawi, AIP Conference Proceedings, 1400, No. 1: (2011); https://doi.org/10.1063/1.3663109

10. Ahmed Hashim and Aseel Hadi, Sensor Letters, 15, No. 12: 1019 (2017); https://doi.org/10.1166/sl.2017.3910

11. Ahmed Hashim and Qassim Hadi, Sensor Letters, 15, No. 11: 951 (2017); https://doi.org/10.1166/sl.2017.3892

12. A. Hadi, F. L. Rashid, H. Q. Hussein, and A. Hashim, IOP Conference Series: Materials Science and Engineering, 518, Iss. 3: 5 (2019); https://doi.org/10.1088/1757-899X/518/3/032059

13. A. Hashim and A. Hadi, Ukrainian Journal of Physics, 63, No. 8: 754 (2018); https://doi.org/10.15407/ujpe63.8.754

14. Ahmed Hashim, Majeed Ali Habeeb, Aseel Hadi, Qayssar M. Jebur, and Waled Hadi, Sensor Letters, 15, Iss. 12: 998 (2017); https://doi.org/10.1166/sl.2017.3935

15. Farhan L. Rashid, Shahid M. Talib, Aseel Hadi, and Ahmed Hashim, IOP Conf. Series: Materials Science and Engineering, 454: 012113 (2018); doi:10.1088/1757-899X/454/1/012113

16. Hind Ahmed, Ahmed Hashim, and Hayder M. Abduljalil, Egypt. J. Chem., 62, No. 4: 1167 (2019); doi:10.21608/EJCHEM.2019.6241.1522 
17. Ahmed Hashim and Zinah Sattar Hamad, J. Nanostruct., 9, No. 2: 340 (2019); doi:10.22052/JNS.2019.02.016

18. D. Hassan and A. Hashim Ah-yasari, Bulletin of Electrical Engineering and Informatics, 8, No. 1: 52 (2019); DOI: 10.11591/eei.v8i1.1019

19. Aseel Hadi, Ahmed Hashim, and Dalal Hassan, Bulletin of Electrical Engineering and Informatics, 9, No. 1: 83 (2020); doi:10.11591/eei.v9i1.1323

20. Abbas Sahi Shareef, Farhan Lafta Rashid, Aseel Hadi, and Ahmed Hashim, International Journal of Scientific \& Technology Research, 8, Iss. 11: 1041 (2019); Water-polyethylene-Glycol-sic-wc-And-ceo2-wcnanofluids-For-SavingSolar-Energy-.pdf (ijstr.org)

21. Hind Ahmed and Ahmed Hashim, International Journal of Scientific \& Technology Research, 8, Iss. 11: 1014 (2019); Fabrication-Of-Novelpvaniosic-Nanocomposites-Structural-Electronic-And-Optical-Properties-ForHumidity-Sensors.pdf (ijstr.org)

22. Ahmed Hashim, Majeed Ali Habeeb, and Aseel Hadi, Sensor Letters, 15, No. 9: 758 (2017); doi:10.1166/sl.2017.3876

23. Farhan Lafta Rashid, Ahmed Hashim, Majeed Ali Habeeb, Saba R. Salman, and Hind Ahmed, Journal of Engineering and Applied Sciences, 8, No. 5: 137 (2013).

24. M. Y. Nadeem, Turk J. Phys., 24: 651 (2000).

25. Alaa J. Kadham, Dalal Hassan, Najlaa Mohammad, and Ahmed Hashim, Bulletin of Electrical Engineering and Informatics, 7, No. 1: 28 (2018); doi:10.11591/eei.v7i1.839

26. Ahmed Hashim and Majeed Ali Habeeb, Transactions on Electrical and Elec tronic Materials, 20, No. 2: 107 (2019); https://doi.org/10.1007/s42341018-0081-1

27. Matthew David Femi, Adrian Ohwofosirai, Aboritoli Sunday, Ogah Sunday B. A. Ezekoye F. I. Ezema, and R. U. Osuji, International Journal of Advances in Electrical and Electronics Engineering, 2, No. 2: 331 (2013).

28. Ahmed Hashim and Noor Hamid, Journal of Bionanoscience, 12, No. 6: 788 (2018); doi:10.1166/jbns.2018.1591

29. Shaymaa Hadi, Ahmed Hashim, and Alaa Jewad, Australian Journal of Basic and Applied Sciences, 5, No. 9: 2192 (2011).

30. Bahaa H. Rabee, and Ahmed Hashim, European Journal of Scientific Research, 60, No. 2: 247 (2011).

31. Ibrahim R. Agool, Firas S. Mohammed, and Ahmed Hashim, Advances in Environmental Biology, 9, No. 11: 1 (2015).

32. Sagadevan Suresh, American Chemical Science Journal, 3, No. 3: 325 (2013); DOI: 10.9734/ACSJ/2013/3503

33. M. H. Hassouni, K. A. Mishjil, S. Chiad, and N. F. Habubi, Physics and Astronomy, 11: 26 (2013).

34. D. Hassan and A. Hashim, Journal of Bionanoscience, 12, Iss. 3: 346 (2018); https://doi.org/10.1166/jbns.2018.1537

35. A. Hashim and Q. Hadi, Journal of Inorganic and Organometallic Polymers and Materials, 28, Iss. 4: 1394 (2018); https://doi.org/10.1007/s10904-0180837-4

36. Falah Ali Jasim, Ahmed Hashim, Angham G. Hadi, Farhan Lafta, Saba R. Salman, and Hind Ahmed, Research Journal of Applied Sciences, 8, Iss. 9: 439 (2013). 
37. Falah Ali Jasim, Farhan Lafta, Ahmed Hashim, Majeed Ali, and Angham G. Hadi, Journal of Engineering and Applied Sciences, 8, No. 5: 140 (2013).

38. Ahmed Hashim and Aseel Hadi, Sensor Letters, 15, No. 10: 858 (2017); https://doi.org/10.1166/sl.2017.3900

39 A. Hashim, M. A. Habeeb, A. Khalaf, and A. Hadi, Sensor Letters, 15, No. 7: 589 (2017); https://doi.org/10.1166/sl.2017.3856

40. Naheda Humood Al-Garah, Farhan Lafta Rashid, Aseel Hadi, and Ahmed Hashim, Journal of Bionanoscience, 12, No. 3: 336 (2018); https://doi.org/10.1166/jbns.2018.1538

41. A. M. Abdelghany, E. M. Abdelrazek, and D. Rashad, Journal of Spectrochimica Acta. Part A: Molecular and Biomolecular Spectroscopy, 130: 302 (2014).

42. D. Hegazy, M. Eid, and M. Madani, Arab Journal of Nuclear Science and Applications, 47, No. 1: 41 (2014).

43. Hind Ahmed, Hayder M. Abduljalil, Ahmed Hashim, Transactions on Elec trical and Electronic Materials, 20: 218 (2019); https://doi.org/10.1007/s42341-019-00111-z

44. Hind Ahmed, Hayder M. Abduljalil, Ahmed Hashim, Transactions on Electrical and Electronic Materials, 20: 206 (2019); https://doi.org/10.1007/s42341-019-00100-2

45. A. Hashim, K. H. H. Al-Attiyah, and S. F. Obaid, Ukr. J. Phys., 64, No. 2: 157 (2019); https://doi.org/10.15407/ujpe64.2.157

46. Ahmed Hashim and Majeed Ali Habeeb, Journal of Bionanoscience, 12, No. 5: 660 (2018); doi:10.1166/jbns.2018.1578

47. A. Hashim and A. Jassim, Journal of Bionanoscience, 12: 170 (2018); doi:10.1166/jbns.2018.1518

48. Ahmed Hashim and Zinah Sattar Hamad, Journal of Bionanoscience, 12, No. 4: 488 (2018); doi:10.1166/jbns.2018.1551

49. G. Attia and M. F. H. Abd El-kader, International Journal of Electrochemical Science, 8: 5672 (2013).

50. A. M. El Sayed and W. M. Morsi, Journal of Materials Science, 49: 4378 (2014).

51. Khalid H. H. Al-Attiyah, Ahmed Hashim, and Sroor Fadhil Obaid, International Journal of Plastics Technology, 23, No. 1: 39 (2019); https://doi.org/10.1007/s12588-019-09228-5

52. Ahmed Hashim and Ali Jassim, Sensor Letters, 15, No. 12: 1003 (2017); https://doi.org/10.1166/sl.2017.3915

53. A. Hashim and Q. Hadi, Journal of Materials Science: Materials in Electronics, 29: 11598 (2018); https://doi.org/10.1007/s10854-018-9257-z

54. Ahmed Hashim and Zinah Sattar Hamad, Journal of Bionanoscience, 12, No. 4: 488 (2018); https://doi.org/10.1166/jbns.2018.1551

55. D. Hassan and A. Hashim, Journal of Bionanoscience, 12, Iss. 3: 341 (2018); https://doi.org/10.1166/jbns.2018.1533

56. M. Venkatarayappa, S. Kilarkaje, A. Prasad, and D. Hundekal, Journal of Materials Science and Engineering A, 1: 964 (2011).

57. A. Hashim, I. R. Agool, and K. J. Kadhim, Journal of Materials Science: Materials in Electronics, 29, Iss. 12: 10369 (2018); https://doi.org/10.1007/s10854-018-9095-z

58. Qayssar M. Jebur, Ahmed Hashim, and Majeed A. Habeeb, Transactions on 
336 Ahmed HASHIM, Alaa J. KADHAM, Aseel HADI, and Majeed Ali HABEEB

Electrical and Electronic Materials, 20: 334 (2019);

https://doi.org/10.1007/s42341-019-00121-x

59. Ahmed Hashim, Yahya Al-Khafaji, and Aseel Hadi, Transactions on Electrical and Electronic Materials, 20: 530 (2019);

https://doi.org/10.1007/s42341-019-00145-3 